\title{
Hydrological Study of Shirol Freshwater Body from Kolhapur District, Maharashtra (India)
}

\author{
S. A. Manjare \\ Department of Zoology, Jaysingpur College, Jaysingpur (M.S), India \\ *Corresponding Author \\ manjaresir_rediffmail.com
}

\begin{abstract}
The present attempt was made to reveal the physico-chemical characteristics of Shirol perennial freshwater body from Kolhapur District (MS) from India. Various physico-chemical parameters were noticed during the period of July 2014 to June 2015 and various parameters like Temperature, Transparency, pH, Electrical Conductivity, Free $\mathrm{CO}_{2}$, Total Hardness, Calcium, Magnesium, Total Alkalinity, Chlorides and Dissolved Oxygen were analyzed monthly from surface water of reservoir. Results revealed that Temperature, Transparency, pH, Electrical Conductivity, Free $\mathrm{CO}_{2}$, Total Hardness, Calcium, Magnesium, Total Alkalinity, Chlorides and Dissolved Oxygen were showed monthly variations. All the parameters were within the acceptable limit hence, the study has concluded that water from reservoir is suitable for drinking and fishing purpose and recommended for commercial fishing.
\end{abstract}

Keywords: Hydrology, freshwater, Shirol, water quality, drinking and fishery

\section{Introduction}

Water is a basic and primary need of all vital processes and it is now well established that the life first arose in aquatic environment. Ever since the pre-historic times man has been intimately associated with water and it has been continuously proved by the evidences of past civilization that all historic human settlements were around inland fresh water resources. Aquatic ecosystem is revolving around the water. Along with aquatic animals, water plays an important role in the life of other animals including human. It is most important natural resource and continuous supply of clean water is mandatory for the survival of all living organisms (Patil et al. 2013). Now-adays huge pressure is being exerted on the water resources because of uncontrolled population growth and ultimately the quality as well as quantity of water has declined. However the water quality of some water reservoirs are in good status and supports both flora and fauna directly or indirectly by balancing ecological parameters (Sachinkumar et al. 2013). As physico-chemical parameters plays a major role in ascertaining the distributional pattern and quantitative abundance of organisms inhabiting a particular ecosystem, the proper categorization of water resources should be made according to their physico-chemical characteristics (Singh et al., 2009).

\section{Study Area}

Kalleshwar freshwater body is situated at Shirol and maintained by Shirol Grampanchayat Shirol. The population of this village is about 30,000 and the annual rainfall of this area is about $120 \mathrm{~mm}$. Water from this reservoir is used for domestic purposes like cloth washing and bathing. Water is also used for animal washing, animal drinking and irrigation purpose. Locally, fishing is also observed during study period.

\section{Collection of Samples}

The samples of surface water were collected monthly from Shirol reservoir during July 2015 to June 2015 for EC, Total Hardness, Calcium, Magnesium, Total Alkalinity and Chlorides. The samples were collected in plastic container in the morning hours and brought to the laboratory for further analysis.

\section{Analysis of Physico-Chemical Properties}

For the analysis, the standard methods were used. Some parameters like Temperature, $\mathrm{pH}$, Transparency was done at the investigation sites. The sample for DO was fixed in the BOD bottle at the sites and then brought to the Laboratory for analysis. Winkler's method was followed for this analysis, while remaining analysis was made by the standard methods of APHA (2005) and Trivedy and Goel (1986)

\section{Results and Discussion}

The results of monthly variation in physico-chemical characteristics of surface water from Shirol freshwater body is given in table 1 .

\section{Temperature}

Temperature is an important parameter for growth of organisms. Atmospheric and water temperature plays an important role in physico-chemical and physiological behavior of aquatic system. It also exerts profound direct or indirect influence on metabolic and physiological behavior of aquatic ecosystems (Welch, 1952). The monthly variation in atmospheric and water values ranges from $26^{\circ} \mathrm{C}$ to $39^{\circ} \mathrm{C}$ and $21^{0} \mathrm{C}$ to $30^{\circ} \mathrm{C}$ respectively. Air temperature was reported highest in the month of April and lowest in the month of August while water temperature was highest during April and May whereas lowest during July. 


\section{International Journal of Science and Research (IJSR) \\ ISSN (Online): 2319-7064}

Index Copernicus Value (2013): 6.14 | Impact Factor (2014): 5.611

\section{Transparency}

Transparency is a characteristic of water that varies with the combined effect of turbidity and color. Turbidity is majorly caused because of silt, clay, planktons and colloidal organic matter which results into low transparency. The values of transparency range between $25 \mathrm{~cm}$ and $60 \mathrm{~cm}$. Transparency value was inclined in the month of November whereas declined in the month of July. Low values of transparency during rainy season may be due to silt brought into the reservoir from adjoining catchment area through rain water while high value of transparency due to gradual settlement of suspended particles. Similar trend of inclined values for transparency during winter and declined during rainy was noted by Thirupathaih et al. (2012).

\section{pH}

The monthly variation in the $\mathrm{pH}$ values ranges between 6.4 and 8.64. $\mathrm{pH}$ values were increased in the month of January and decreased in the month of May. Similar trend of increased $\mathrm{pH}$ during winter and decreased during summer was given by Mathivanan et. al. (2005). Kaul and Handoo (1980) emphasized that increased surface water $\mathrm{pH}$ in water bodies is due to increased metabolic activities of autotrophs, because in general they utilize the $\mathrm{CO}_{2}$ and liberates $\mathrm{O}_{2}$ thus reducing $\mathrm{H}^{+}$ions. In water bodies liberation of acids from decomposing organic matter under low concentration result in low $\mathrm{pH}$ and usually decomposition of organic matter takes place during summer months.

\section{Electric Conductivity}

The monthly variation in the values of EC ranges from $0.057 \mathrm{mhos} / \mathrm{cm}$ to $0.23 \mathrm{mhos} / \mathrm{cm}$. EC values were seen decreased in the month of June and increased in the month of April. Higher values during summer months may be due to the accumulation of ions owing to evaporation, biological turn over and interaction of sediments. Dilution of water during rainy season causes decreased EC due to addition of rain water. Similar trend of decreased EC during rainy season while increased during summer season was given by Pushpendra and Madhyasatha (1994).

\section{Free $\mathrm{CO}_{2}$}

Free $\mathrm{CO}_{2}$ is essential for photosynthesis and its concentration affects the phytoplankton, and its productivity. Excess of it gets dissociated into carbonic acid. The limit of free $\mathrm{CO}_{2}$ as per acceptable Standards is $10 \mathrm{mgL}-1$ of surface water. Increase in $\mathrm{CO}_{2}$ indicates increase in pollution load (Koshy and Nayar, 1999). Free $\mathrm{CO}_{2}$ values ranges from $4.4 \mathrm{mg} / \mathrm{l}$ to $13.2 \mathrm{mg} / \mathrm{l}$. Particular trend of $\mathrm{CO}_{2}$ value was not observed during the study period, it was fluctuating throughout the year.

\section{Total Hardness}

Hardness is the property of water which prevents lather formation with soap and increases the boiling point of water. The anions responsible for hardness are mainly bicarbonate, carbonate, sulfate, chloride, nitrate and silicates, etc. The monthly variation in total hardness ranges from $30 \mathrm{mg} / 1$ to $64 \mathrm{mg} / \mathrm{l}$. It was minimum in the month of June whereas maximum in the month of December. It was minimum during rainy season because of dilution due to rain water and maximum during winter season because of leaching salts from the catchment area. Similar trend of higher in winter and lower in rainy season was given by Sarma and Dutta (2012) and Sayeswara et al. (2012).

\section{Calcium}

Calcium, in the form of the $\mathrm{Ca}^{2+}$ ion, is one of the major inorganic cations, or positive ions, in saltwater and freshwater. Calcium ion concentration was show monthly variation from $5.61 \mathrm{mg} / \mathrm{l}$ to 17.64. It was lower in the month of August whereas higher in the month of December. Minimum values of calcium ion concentration during rainy season might be due to greater dilution addition of rain water whereas maximum during winter season might be due to leaching of underground aquifers leach even higher concentrations of calcium ions from rocks and soil. Calcium carbonate is relatively insoluble in water, but dissolves more readily in water containing significant levels of dissolved carbon dioxide.

\section{Magnesium}

Magnesium is often associated with calcium in all kinds of waters but its concentration remains generally lower than the calcium (Venkatsubramani and Meenmbal, 2007). The monthly variation in magnesium ion concentration values ranges from $4.75 \mathrm{mg} / 1$ to $11.26 \mathrm{mg} / \mathrm{l}$. It was minimum in the month of June and maximum in the month of December. Similar trend of higher during winter and lower during rainy was also noted by Verma et al. (2011).

\section{Alkalinity}

In pure natural water alkalinity is mostly due to dissolved $\mathrm{CO}_{2}$ or carbonate ions and it represents the main carbon source for assimilation during photosynthesis. The monthly variation in the alkalinity values ranges from 10 $\mathrm{mg} / \mathrm{l}$ to $30 \mathrm{mg} / \mathrm{l}$. The alkalinity values inclined in the month of November whereas declined in the month of April. Similar trend of inclined alkalinity during winter was given by Latha and Mohan (2010) while declined alkalinity during summer was reported by Rahul (2012). According to Kaul et al. (1980) increase in atmospheric temperature and the consequent increase in photosynthetic process in hot season, alkalinity values usually decrease in summer.

\section{Chlorides}

Chloride is an important parameter in assessing the water quality. It controls the salinity of water and osmotic stress on biotic communities (Banerjee, 1967). The monthly variation in the chloride values ranges between $14.2 \mathrm{mg} / \mathrm{l}$ and $36.82 \mathrm{mg} / \mathrm{l}$. It was observed minimum in the month of July and maximum in the month of March. Chloride values were higher during summer might due to high 


\section{International Journal of Science and Research (IJSR) \\ ISSN (Online): 2319-7064 \\ Index Copernicus Value (2013): 6.14 | Impact Factor (2014): 5.611}

anthropogenic and animal activities whereas lower during rainy season might be due to dilution of rain water and decreased anthropogenic and animal activities. Similar trend of chloride ion concentration was given by Garg et al. (2011).

\section{Dissolved Oxygen}

The oxygen content of water body is one of the important parameter in quality assessment. It presence is essential in aquatic ecosystems to keep the organisms in balance. It also affects the solubility and availability of many nutrients hence affecting the productivity of aquatic ecosystems (Wetzel, 1983). The monthly variations in dissolved oxygen values range from $6.4 \mathrm{mg} / 1$ to $15.2 \mathrm{mg} / \mathrm{l}$. It was minimum in the month of April while maximum in the month of December. Lower oxygen content were observed during summer season due to DO decreases with increased temperature and oxygen level increased during winter season because of DO increases with decreased temperature. The trend of dissolved oxygen maximum in winter season and minimum in summer season was also given by Tiwari and Ranga (2012) and Sinha and Biswas (2011).

\section{Conclusions}

Present study can be concluded that the water from this reservoir is of potable quality. It has also been concluded that the water is suitable for the commercial fish culture and recommended to the commercial fishing in the water reservoir as the reservoir is of perennial type.

\section{References}

[1] Abhaykumar Rahul, M. K. S. Kushawaha, R. Mathur, Shashi Rahul Akash Yadav (2012). Assessment of freshwater quality of Angori reservoir, District Datia, Madhya Pradesh. Nat. Envi. and Poll. Tech. 11 (4): 667-669.

[2] APHA, AWWA and WPCF (2005). Standard methods for examination of water and waste water, $21^{\text {st }}$ edition, American Public Health Association, New York.

[3] Banarjee S. M. (1967). Water quality and soil condition of fishponds in states of India in relation to fish production. Indian J. Fisheries, 14 (1 \& 2): 115 144.

[4] Goel, P. K., Gopal, B. and Trivedi, R. K. (1980). Impact of sewage on freshwater ecosystem. Int. J. Ecol. and Envir. Sci. 6: 97-116.

[5] Islam A. M., Chuodry A. N. and Zaman M. (2001). Limnology of fish ponds in Rajasthani Bangladesh. Eco. Environ. Conser. 7: 1-7.

[6] Kaul, V. and J. K. Handoo (1980). Physicochemical characteristics of Nilang-a high altitude forest Lake of Kashmir and its comparison with valley lakes. Proc Indian National Science Acad. B. 46 (4): 528-541.

[7] Koshy, M. \& T. V. Nayar (2000). Water quality of River Pamba at Kozencherry, Poll. Res. 19 (4), pp. $665-668$.

[8] Medudhula Thirupathaiah, Ch. Sampata, Chintha Sammaiah (2012). Analysis of water quality using physico-chemical parameters in lower manair reservoir of Karimnagar District, Andhra Pradesh. International J. of Environ. Sci. Vol. 3, No. 1: 172180.

[9] N. Latha and Ramachandra Mohan (2010). Studies on enviro-ecological status of Kommagatta Lake of Bangalore, Karnataka. Indian Hydrobiology, 12 (2): 126-129.

[10] P. U. Verma, D, K. Chandawat and H. A. Solanki (2011). Seasonal variation in physico-chemical and phytoplankton analysis of Kankaria Lake. Life sciences leaflets, 19: 842-854.pp.49-63.

[11] Patil, S. R., Sawant, R. S., Patil, S. S., Sathe, T. V. and Patil, R. S. (2013). Avian fauna and Physicochemical Parameters of Gajargaon Pond of Ajara Tahsil, Kolhapur (M. S.). Rasayan J. Chem. 6(1):7679.

[12] Pushpendra and M. N. Madhyastha (1999). Seasonal variation of certain chemical parameters in soil-water phases in a small pond along western India. $J$. Ecobiol. 6 (4): 311-313.

[13] R. K. Garg, R.J. Rao, D. Uchachariya, G. Shukla and D. N. Saksena (2010). Seasonal variations in water quality and major threats to Ramsagar reservoir, India. AJEST, 4(2): 061-076.

[14]Radhika, C. G., I. Mini \& T. Gangadevi (2004). Studies on abiotic parameters of a tropical fresh water lake - Vellayani Lake, Trivandrum, Kerala, Poll. Res. 23(1).

[15] Sachinkumar Patil, S. S. Patil and T. V. Sathe (2013). Limnological status of Khanapur freshwater reservoir from Ajara tahsil, Kolhapur district (MS), India. IJSET, 2 (6): 1163-1174.

[16] Sankar Narayan Sinha and Mrinal Biswas (2011). Analysis of physico-chemical characteristics to study the water quality of a lake in Kalyani, West Bengal. Asian J. Exp. Sci. Vol. 2 (1): 18-22.

[17] Sarma, D. and Dutta, A. (2012). Ecological studies of two riverine wetlands of Goalpara District of Assam, India. Nat. Envi. and Poll. Tech. 11 (2): 297-302.

[18] Sayeshwara, H. A., Mahesh Anand Goudar and M. Ravikumar (2010). Limnological studies of Santhekadur pond, Bhadravathi, Karnataka, India. Geobios, 36 (4): 293-296.

[19] Singh Santhoshkumar A., Dakua D. and Biswas S. P. (2009). Physico-chemical parameters and fish enumeration of Maijan Beel (wetland) of Upper Assam. Geobios, 36: 184-188.

[20] Tiwari Mamata and Ranga, M. M. (2012). Assessment of diurnal variation of physio chemical status of Khanapura Lake, Ajmer, India. Res.J.Chem.Sci. 2(7): 61-64.

[21] Trivedi R. K. and P. K. Goel (1986). Chemical and biological methods for water pollution status. Environmental Publication, Karad (India).

[22] V. Mathivanan, P. Vijayan and Selvi Sabhanayakam (2005). An assessment of water quality of river Cauvery Mettur, Salem District, Tamil Nadu in relation to pollution. Edited by Arvind Kumar Fundal. Limn: 36-43.

[23] Venkateshwarlu M., Shanmugum M. and Chinchana N. V. (2003). Biodiversity of fish fauna of Mudogodu tank, Rangenhalli. Ecol. Envi. 21: 161-164. 


\section{International Journal of Science and Research (IJSR) \\ ISSN (Online): 2319-7064}

Index Copernicus Value (2013): 6.14 | Impact Factor (2014): 5.611

[24] Venkatsubramani, R. and Meenambal, T. (2007). Study of subsurface water quality of Mathupalayan Taluka of Coimbatore District, Tamil Nadu. Nat. Envi. and Poll. Tech. 6: 307-310.

[25] Welch P. S. (1952). Limnology, $2^{\text {nd }}$ edition, McGraw Hill Book Co. New York.
[26] Wetzel R. G. (1983). Limnology, W. B. Saunders Company, London.

[27] WHO (1999). Guideline for drinking water quality, $2^{\text {nd }}$ edition. World Health Organization, Geneva, 1: $30-113$

Table 1: Monthly Variation in physico-chemical parameters of Shirol freshwater body during 2014-15

\begin{tabular}{|c|c|c|c|c|c|c|c|c|c|c|c|c|}
\hline Month/ Parameter & $A T$ & WT & Transparency & $p H$ & $E C$ & Free $\mathrm{CO}_{2}$ & T. H. & Calcium & Magnesium & TA & Chloride & DO \\
\hline July & 27 & 21 & 25 & 7.82 & 0.163 & 8.8 & 30 & 10.42 & 13.01 & 22 & 14.2 & 8 \\
\hline August & 26 & 22 & 39 & 7.5 & 0.128 & 8.8 & 32 & 5.61 & 6.41 & 16 & 17.04 & 9.6 \\
\hline September & 28 & 22 & 40 & 7.48 & 0.115 & 4.4 & 48 & 11.22 & 8.93 & 24 & 19.88 & 8 \\
\hline October & 27 & 20 & 48 & 7.57 & 0.17 & 4.4 & 44 & 12.03 & 7.76 & 14 & 19.08 & 9.2 \\
\hline November & 28 & 23 & 60 & 7.86 & 0.18 & 8.8 & 44 & 13.63 & 7.37 & 30 & 25.06 & 6.4 \\
\hline December & 27 & 22 & 56 & 7.85 & 0.18 & 13.2 & 64 & 17.64 & 11.26 & 16 & 31.24 & 15.2 \\
\hline January & 29 & 21 & 55 & 8.64 & 0.17 & 8.8 & 54 & 16.04 & 9.22 & 16 & 25.56 & 12.8 \\
\hline February & 31 & 22 & 55 & 7.35 & 0.1 & 8.8 & 46 & 13.63 & 7.83 & 26 & 19.88 & 7.6 \\
\hline March & 34 & 26 & 39 & 7.58 & 0.125 & 4.4 & 50 & 12.83 & 9.03 & 20 & 36.92 & 7.2 \\
\hline April & 36 & 30 & 33 & 7.64 & 0.23 & 8.8 & 32 & 10.42 & 5.24 & 10 & 31.24 & 6.4 \\
\hline May & 35 & 30 & 31 & 6.4 & 0.078 & 8.8 & 32 & 12.03 & 6.41 & 16 & 28.4 & 8 \\
\hline June & 27 & 23 & 34 & 6.9 & 0.057 & 13.2 & 30 & 10.42 & 4.75 & 16 & 19.88 & 7.6 \\
\hline
\end{tabular}

Note: All values are in $\mathrm{mg} / \mathrm{l}$ except temperature $\left({ }^{0} \mathrm{C}\right)$, transparency $(\mathrm{cm}), \mathrm{pH}$ and E.C $(\mathrm{mhos} / \mathrm{cm})$ 